\title{
TOXIC SUBSTANCES FROM COAL COMBUSTION- FORMS OF OCCURRENCE ANALYSES
}

\author{
Semiannual Report
}

Submitted to the U.S. Department of Energy

\author{
By \\ U.S. Geological Survey \\ Eastern Energy Resources \\ 956 National Center \\ 12201 Sunrise Valley Drive \\ Reston, VA 20192 \\ DOE Contract DE-FG22-95PC95145--05
}

Phase II

September 30, 1998*

*Includes semiannual report for March 31, 1998 


\section{Introduction}

Detailed information on trace-element modes of occurrence in coal is essential to understanding and predicting trace-element transformations taking place during coal combustion. The USGS has developed quantitative and semi-quantitative methods for determining the mode of occurrence of trace elements in coal. This information is needed to generate predictive models for trace-element behavior, the ultimate goal of this integrated study. While the USGS has a relatively small part of the overall study, the results have direct bearing on the predictive equations being developed as the primary product of this program.

The USGS procedure uses an iterative selective leaching protocol on whole coals in combination with a range of complementary studies. The sequence of leaching steps, and the intended results, are as follows: 1) exchangeable cations, and a fraction of the carbonate-hosted cations are removed by ammonium acetate; 2) cations primarily associated with carbonates and monosulfides such as galena, sphalerite and chalcopyrite are removed by hydrochloric acid; 3) silicate-associated cations are removed by hydrofluoric acid; and 4) elements associated with di-sulfides (pyrite and marcasite) are removed by nitric acid. The amount of an element leached by a given reagent is compared to concentrations of that element in the whole coal to obtain the fraction of an element having the indicated residence. Elements not leached by any of the four reagents may be present in the organic portions of the coal, or in insoluble phases such as zircon or titanium dioxides. Additionally, where mineral grains are completely encased by the organic matrix, these "shielded" grains may not be completely digested. Quantitative results are obtained by interpreting the leaching data together with the results obtained by complementary techniques such as electron microprobe analysis.

The electron microprobe is used to determine minor and trace elements on a grain scale, on points selected by the operator. In Phase I, this technique proved to be especially useful for pyrite grains, as many of the HAP's elements of interest proved to be present at concentration levels about the minimum detection limit of about $100 \mathrm{ppm}$. Other essential components of the USGS procedure include semi-quantitative determination of mineralogy by X-ray diffraction (XRD) analysis of low temperature ash (LTA), and confirmation of mineralogy for operator-selected grains using a scanning electron microscope (SEM) equipped with an energy-dispersive X-ray analyser (EDX).

The USGS approach complements results obtained by X-ray absorption fine structure (XAFS) by our colleagues at the University of Kentucky. The USGS technique also provides data for elements such as Se and $\mathrm{Hg}$, whose concentrations are commonly too low to obtain XAFS spectra, and for elements with atomic numbers beyond the current XAFS atomic number range of about 20 to 42 (Ca to $\mathrm{Mo}$ ). For elements that are common to the two approaches, such as As and $\mathrm{Cr}$, comparison of results obtained by the USGS with those obtained by XAFS proved to be an important outcome of Phase I.

\section{Phase II Work Scheduled and Accomplishments}

Work proposed under Phase II includes trace element mode of occurrence determinations, primarily by the techniques described above for three new coal samples: Ohio 5/6/7, North Dakota lignite, and Wyodak. The Ohio and North Dakota samples were received in June 1998. Splits of these coals were sent to Geochemical Testing, Inc. of Somerset, PA, for Proximate, Ultimate, BTU, FSI, Ash Fusion, Sulfur Forms and Air Dry Loss testing. Results of these tests were received in July and are given in Appendix 1. The Wyodak sample was received in August 1998. Test results are not yet available for the Wyodak sample. 
Other tasks re-commencing in the third and fourth quarters of FY 1998 include selective leaching of project samples, chemical analysis of whole coals, leachates and solid residues, and preparation for probe/SEM studies, LTA/XRD, and Ion Probe.

\section{Leaching Studies}

During the reporting period, duplicate splits of the Ohio 5/6/7 and North Dakota samples were taken through all 4 steps of the selective leaching procedure. The solid residues from these procedures were sent to Denver for analysis; results have not yet been returned. In addition, splits of these two samples were sent to Denver to begin determination of the 47-element USGS whole-coal package. The whole-coal determinations utilize a combination of methods including instrumental neutron activation analysis (INAA), inductively coupled plasma atomic emission spectroscopy (ICP-AES), inductively coupled plasma mass spectrometry (ICP-MS), and element specific methods for Se (hydride-generation) and $\mathrm{Hg}$ (cold-vapor atomic fluorescence). Results for the whole-coal splits are not yet available. As of this writing, leaching procedures for the Wyodak sample are commencing. A new ICP-AES unit was installed in our analytical labs in Denver over the summer.

\section{Probe/SEM and LTA/XRD}

Because of the time involved in obtaining the results of the leaching and whole-coal elemental analyses, first priority was given to these procedures. Now that these studies are underway, supporting studies conducted in-house are commencing. Preparation of polished coal/epoxy pellets for probe/SEM studies is underway. An ASTM procedure is used (ASTM, 1997) as discussed in the Phase I final report. Once the pellets are available, blocks of microprobe and SEM machine time will be reserved for sample characterization. Preparation of low-temperature ash for XRD analysis is underway.

\section{Ion Probe}

In keeping with our goal of developing new quantitative methods for direct determination of trace element concentrations in coal components, we have begun exploratory work using the Cameca of Secondary Ion Mass Spectrometer (Ion Probe) at the Carnegie Institution of Washington, Department of Terrestrial Magnetism (DTM). In our initial visit to DTM, in March 1998, we concentrated on determining Hg in sulfides. We found that $\mathrm{Hg}$ ionization was not sufficient for us to obtain useful results. Ionization of $\mathrm{Ni}$ in pyrite was relatively good, suggesting that if necessary, we could measure $\mathrm{Ni}$ at concentrations below 100 ppm, the detection limit for the electron microprobe. A second visit is scheduled for early 1999, during which we will concentrate on determining the Cr content of illite, found to be near the detection limit for electron probe analysis ( $200 \mathrm{ppm})$, in Phase I.

Our experience in the one ion probe session, together with discussion with DTM staff, will result in optimization of sample preparation procedures for ion probe analysis. For example, in the very high vacuum $\left(\sim 10^{-9}\right.$ torr $)$ of the ion probe, degassing of coal/epoxy pellets prepared for microprobe/SEM studies was found to be a significant problem, requiring pump-down times of at least $24 \mathrm{hrs}$. for each sample change. In future work, polished thin sections of coal will used for ion probe studies, in order to alleviate the sample degassing problem. 


\section{Priorities for upcoming work}

At present, the proposed leaching studies are well underway. In the first half of FY 1999, priority will be given to completing the first round of leaching studies and obtaining supporting probe, SEM, and XRD analyses. Completion of manuscripts resulting from the Phase I collaboration will also be a high priority, as well as continuing development work on trace element microanalysis (ion probe), and improving results for mercury (see below).

\section{New procedures in Phase II}

Procedures are being revised to correct two recurring problems encountered in Phase I. In the first problem, results for $\mathrm{Hg}$ were found to be difficult to interpret due to the relatively poor detection limit (0.02 ppm) obtainable by the cold vapor atomic absorption (CVAA) method. In Phase II, Hg sensitivity will be greatly increased by using the cold vapor atomic fluorescence (CVAF) method. Development work for these analyses is underway in our labs in Denver.

Another problem encountered in Phase I involved low totals for some leaching results. For example, this problem was encountered for the Elkhorn/Hazard sample, in the nitric acid leaching step (see below). The low totals are probably due to incomplete sample digestion, but may also be due to readsorption of metals in solution onto residual organics. Procedural changes in Phase II include routine SEM examination of residues after leaching, and where necessary, low temperature ashing of solid residues. Preliminary tests (for Cr only) comparing our standard procedure of washing solid residues with distilled water vs. washing with ammonium acetate indicate that readsorption of metals onto residual organics is not significant.

In Phase I, we reported on the mode of occurrence of iron and 5 important HAP's elements: arsenic, selenium, chromium, nickel, and mercury. While these data were sufficient for the requirements of Phase I, we routinely determine a much wider range of elements, and plan to do so in Phase II. For example, in a recent report to the International Energy Agency (Palmer et al., 1998), we report on the mode of occurrence of 35 elements and the rare earth elements as a group. Expanding the number of elements determined will be useful in interpreting Phase II vaporization studies. For example, Phase I combustion experiments showed that in addition to As and Se, $\mathrm{Zn}$ and Sb were highly volatile during combustion (Senior, et al., 1997). Information on the mode of occurrence of these elements would have been useful for interpreting Phase I results. Analysis of a larger group of elements might also help show the behavior of more refractory elements in the combustion process.

\section{Revision and Clarification of Phase I Results}

Review of Phase I results was conducted during the hiatus leading up to the start of Phase II. Most of the changes are included in a revised Final Technical Report for Phase I, submitted on November 30, 1997 (Crowley et al., 1997). Much of the discussion concerned the Elkhorn/Hazard sample, in which pyrite digestion during the nitric acid leaching step was found to be incomplete, giving results for pyriteassociated elements such as arsenic and iron that are considered to be too low. As a result, the fraction of arsenic in pyrite determined (25\%) was adjusted to the maximum value $(65 \%)$, assuming that all of the unleached arsenic in this sample (40\%) occurred in pyrite. The actual value for percent arsenic in pyrite must be somewhere between $25 \%$ and $65 \%$. Subsequent re-leaching of the Elkhorn/Hazard sample has been completed. SEM examination of the re-leached solid residue showed that all of the pyrite had been digested. We are awaiting ICP-MS results for As. Results for $\mathrm{Cr}$, Ni and $\mathrm{Fe}$ are not available as well, due 
to the shutdown to install the new ICP-AES instrument in Denver. Re-leaching results for Se show the nitric acid fraction (20\%) did not change. Results for $\mathrm{Hg}$ changed from $0 \%$ to $20 \%$. An attachment giving the final nitric acid leaching values for all 6 elements in the Elkhorn/Hazard sample will be included in the next semiannual report.

In the revised Final Technical Report, changes were also made to chromium results for the Pittsburgh sample, based on refinements to the calculation procedure. In addition, revisions were made to the results for mercury in the Illinois \#6 and Pittsburgh samples. A letter to PSI outlining the changes in the Phase I results as of March, 1998, is included here as Appendix 2.

Based on discussions with DOE and PSI, and examination of the Phase I Final Project report, we felt that a clarification of the USGS volatilization experiments conducted in Phase I was necessary. This was done in an August, 1998 letter to PSI included here as Appendix 3. The USGS study shows no systematic differences between samples heated at $550{ }^{\circ} \mathrm{C}$ (where no volatilization is expected) and samples heated at $1000{ }^{\circ} \mathrm{C}$. Chromium is an exception; the $1000^{\circ} \mathrm{C}$ data for $\mathrm{Cr}$ are suggestive of a contamination problem (Appendix 3).

\section{Phase I Publications}

Publications resulting from USGS participation in Phase I are listed in Appendix 4. A special issue of Fuel Processing Technology, edited by G. P. Huffman, will be devoted to the Phase I study. Papers comparing results using the USGS procedure and the XAFS procedure have been prepared for chromium, and for arsenic modes of occurrence in the four Phase I coals. Abstracts of these two collaborative papers are given in Appendix 5.

\section{Summary}

All aspects of the USGS participation in Phase II are ongoing or will re-commence shortly. The leaching and bulk chemical studies were given first priority because of the time needed to complete these analyses. Now that the leaching studies are in progress, supporting studies done in-house, such as electron microprobe, SEM, LTA and XRD are being initiated. Priority is also being given to completion of publications from Phase I, and to development of new procedures proposed under Phase II. 


\section{References}

ASTM (American Society for Testing and Materials) 1997, Annual Book of ASTM Standards v. 5.05, Gaseous Fuels, Coal and Coke, ASTM, Philadelphia, 526 p.

Crowley, S. S., Palmer, C. A., Kolker, Allan, Finkelman, R. B., Kolb, K. C., Belkin, H. E., Willett, J. C. Mroczkowski, S. J., Bullock, J. H., Jr., and Motooka, J., 1997, Toxic substances from coal combustion- Forms of occurrence analysis: Final Technical Report, DE-AI22-95PC95145, 63 p. (revised November 30, 1997).

Palmer, C. A., Kolker, Allan, Willett, J. C., Mroczkowski, S. J., Finkelman, R. B., Taylor, K. C., Dulong, F. T., and Bullock, J. H., Jr., 1998, Draft Final Report on the IEA mode of Occurrence Round Robin, Phase 1: International Energy Agency, London, 62 p.

Senior, C. L., Bool, L. E., III, Morency, G. P., Huggins, F., Huffman, G. P., Shah, N., Wendt, J. O. L., Shadman, F., Peterson, T., Seames, W., Wu, B., Sarofim, A. F., Olmez, I., Zeng, T., , Crowley, S. S., Kolker, Allan, Palmer, C. A., Finkelman, R. B., Helble, J. J., and Wornat, M. J., 1997, Toxic substances from coal combustion- a comprehensive assessment: Final Report, DOE Contract DEAC22-95PC95101, U.S. Department of Energy, Federal Energy Technology Center, Pittsburgh, PA, September, 1997. 
APPENDICES 
Appendix 1 Summary of coal test results for the Ohio 5/6/7 and North Dakota samples (As received basis).

\begin{tabular}{|l|c|c|}
\hline & OHIO 5/6/7 & $\begin{array}{c}\text { NORTH } \\
\text { DAKOTA }\end{array}$ \\
\hline PROXIMATE ANALYSIS & & \\
\hline Moisture & 2.33 & 35.88 \\
\hline Ash & 9.70 & 9.38 \\
\hline Volatile Matter & 39.19 & 28.15 \\
\hline Fixed Carbon & 48.78 & 26.59 \\
\hline TOTAL & 100.00 & 100.00 \\
\hline & & \\
\hline ULTIMATE ANALYSIS & & 6.59 \\
\hline Hydrogen & 5.07 & 38.57 \\
\hline Carbon & 71.07 & 0.42 \\
\hline Nitrogen & 1.37 & 0.63 \\
\hline Sulfur & 2.62 & 44.41 \\
\hline Oxygen & 10.17 & 9.38 \\
\hline Ash & 9.70 & 100.00 \\
\hline TOTAL & 100.00 & \\
\hline & & 0.09 \\
\hline FORMS OF SULFUR & & 0.18 \\
\hline Sulfate & 0.02 & 0.36 \\
\hline Pyritic Sulfur & 1.39 & \\
\hline Organic Sulfur & 1.21 & \\
\hline & & \\
\hline HEATING VALUE (BTU/lb) & 12865 & \\
\hline & & \\
\hline & & \\
\hline
\end{tabular}


Appendix 2. Letter to PSI Inc. outlining changes including in revised Phase I final report.

March 31, 1998

Connie Senior

PSI

20 New England Business Center

Andover, MA 01810-1077

Dear Connie:

Enclosed please find a copy of our revised final technical report to PSI. A copy in .wpd format is also enclosed on disk. This report is the same as the one sent to you in early December. No further changes have been made. The changes made as of November 30, 1997 were as follows:

1) p.9, under Arsenic, Elkhorn/Hazard Coal, we have added the last three sentences of the $2^{\text {nd }}$ paragraph. ("Preliminary work..." to “...become available.") The comments address the finding that a subsequent re-leaching of the Elkhorn/Hazard residual with $\mathrm{HNO}_{3}$ has removed all of the pyrite. This has been confirmed by SEM and an analysis of the leachate for iron. Final arsenic numbers will be reported as soon as they are available.

2) p.10, under Iron, $2^{\text {nd }}$ and $3^{\text {rd }}$ to last sentences of $2^{\mathrm{ND}}$ paragraph. ("Subsequent leaching...remaining iron.") Again, addressing the fact that re-leaching the Elkhorn/Hazard residual has removed all of the pyrite, and accounted for all of the iron.

3) p.10 under $\underline{\text { Selenium, }}, 2^{\text {nd }}$ sentence. “...Elkhorn/Hazard coal, where selenium was primarily leached by nitric acid (20\%)." The previous value was $50 \%$. This was apparently a typo.

4) p.11 under Selenium, $2^{\text {nd }}$ paragraph, the last sentence was added. ("In the Elkhorn/Hazard coal corrections were made for un-leached pyrite as discussed above.") This sentence refers to corrections made to Figure $6 \mathrm{c}$ where the amount of Se attributable to pyrite in the Elkhorn/Hazard coal is now $50 \%$ not $20 \%$ as previously reported.

5) p.11 under Chromium, first paragraph. Changes have been made to the leaching values for the Pittsburgh coal. The previous values were $0 \%, 20 \%, 25 \%$, and $30 \%$ for $\mathrm{NH} 4 \mathrm{Ac}, \mathrm{HCl}, \mathrm{HF}$, and $\mathrm{HNO}_{3}$ respectively for a total of $75 \%$ leached. The corrected values are $0 \%, 10 \%, 15 \%$, and $5 \%$ for a total of $30 \%$ leached. These changes are also reflected in Figure $5 \mathrm{~d}$ 
6) p.12 under Nickel, last sentence was added. ("The percent $\mathrm{Ni}$ in pyrite for the Elkhorn/Hazard coal has been corrected for the additional pyrite as for As and Se above.") This sentence refers to corrections made to Figure $6 \mathrm{~d}$ where the amount of Ni attributable to pyrite in the Elkhorn/Hazard coal is now $15 \%$ not $5 \%$ as previously reported.

7) p.12 under Mercury, the discussion has substantial changes as does Figure $5 \mathrm{f}$. The changes are to the percent leached values for the Pittsburgh and Illinois \#6 coals. In the Pittsburgh coal the percent leached value for $\mathrm{HNO}_{3}$ has gone from 10 to $60 \%$ resulting in a total of $90 \%$ leached, up from $40 \%$. The Illinois \#6 coal has changed from only 5\% leached by $\mathrm{HF}$ to $20 \%$ by $\mathrm{HCl}, 0 \%$ by $\mathrm{HF}$, and $65 \%$ by $\mathrm{HNO}_{3}$ for a total of $85 \%$ leached.

Although not mentioned above, minor changes have been made to Figures 5a-c, e and 6a and b. Specifically, subscripts and borders were corrected in Figure 5, and zero values were removed from Figure 6. All other figures in the report remain unchanged from the previous version. Allan will be out of the office until April $6^{\text {th }}$.

If you have any questions please do not hesitate to call me at (703) 648-6489.

Sincerely,

Stanley J. Mroczkowski 
Appendix 3. Letter to PSI Inc. explaining results of Phase I volatilization experiments.

Reply To: Mail Stop 956

Dr. Connie Senior

August 18, 1998

Physical Sciences, Inc.

20 New England Business Center

Andover, MA 01810-1077

Dear Connie:

In reading over the recent quarterly report (No. 7), it seems that there is still some confusion on the issue of the Phase I volatility studies (section 3.2.4). As presented, the USGS results, in which no systematic losses were found, and the MIT results, in which possibly significant losses were found, appear to be contradictory. Upon closer examination, however, this is not necessarily the case, for the following reasons:

1) The experiments are not directly comparable. The USGS procedure compared trace element contents of ash prepared at $550{ }^{\circ} \mathrm{C}$ with that prepared at $1000{ }^{\circ} \mathrm{C}$, both recalculated to a whole-coal basis. Elements determined were measured by ICP-MS/ICP-AES, including As, $\mathrm{Cr}, \mathrm{Ni}, \mathrm{Co}, \mathrm{Sb}, \mathrm{Pb}, \mathrm{Cd}, \mathrm{Zn}, \mathrm{Be}, \mathrm{Mn}$, Th, U, etc. These techniques use an acid digestion procedure to get the ash into solution for analysis. Because this procedure requires ashing of the coal to make the determinations, we did not measure and compare the concentrations before and after ashing at each temperature, as stated in section 3.2.4. Because whole coal cannot readily be digested for analysis by ICP-MS/ICP-AES, such a comparison requires that the coal be analyzed by INAA or a comparable method, as was done in the MIT experiments. In our volatilization experiments, we did not find systematic differences between the $550{ }^{\circ} \mathrm{C}$ ash and the $1000{ }^{\circ} \mathrm{C}$ ash. No determinations were made on ash prepared at $200{ }^{\circ} \mathrm{C}$, contrary to what is stated in the report. The reason why $550{ }^{\circ} \mathrm{C}$ is often used in preparation of coal ash for analysis is that this temperature has been found to be low enough to NOT result in volatilization for most elements. The $550{ }^{\circ} \mathrm{C}$ ash was prepared not because we expected volatilization at this temperature, but rather, as a baseline for comparing the $1000^{\circ} \mathrm{C}$ ash. The results of our experiments are attached (p. 3-4).

2) The ashing devices and procedures are not directly comparable. In the USGS apparatus, the temperature is ramped up slowly, over several hours. In the MIT procedure, the sample was lowered directly into the hot zone of a furnace at $890^{\circ} \mathrm{C}$. While this may be more like what happens during coal combustion, the techniques are different enough that the results may not be directly comparable.

3) In the MIT experiments, Se shows the greatest degree of volatilization. This behavior is well known, and for this reason, we use a whole coal technique for Se (hydride generation) and do not measure Se on coal ash. As a result, we did not compare Se contents of the ash prepared at $550{ }^{\circ} \mathrm{C}$ with the $1000{ }^{\circ} \mathrm{C}$ ash. 
4) As an additional comment, I would like to point out that because elements such as $\mathrm{Cr}, \mathrm{Co}, \mathrm{Sc}$, $\mathrm{La}$, etc. occur in coal as minerals, or are organically associated, and do not occur as pure elements, under no circumstances would we expect their pyrolysis temperature to be the same as the melting point for the pure element. I think this is what you are trying to say in section 3.2.4, but we are not surprised by this finding.

I hope this helps clarify the Phase I volatilization experimental results, and I'm sorry if any of the confusion resulted from information I provided .

Sincerely,

Allan Kolker

Geologist

CC: Gene Dalverny, FETC

Attachment: USGS Phase I volatilization data.

\begin{tabular}{|l|c|c|c|c|c|c|c|c|}
\hline & \multicolumn{2}{|c|}{ Wyodak } & \multicolumn{2}{c|}{ Elkhorn/Hazard } & \multicolumn{2}{c|}{ Pittsburgh } & \multicolumn{2}{c|}{ Illinois \#6 } \\
\hline & $550{ }^{\circ} \mathrm{C}$ & $1000{ }^{\circ} \mathrm{C}$ & $550{ }^{\circ} \mathrm{C}$ & $1000{ }^{\circ} \mathrm{C}$ & $550{ }^{\circ} \mathrm{C}$ & $1000{ }^{\circ} \mathrm{C}$ & $550{ }^{\circ} \mathrm{C}$ & $1000{ }^{\circ} \mathrm{C}$ \\
\hline $\mathrm{As}$ & 1.58 & 1.41 & 5.12 & 5.49 & 4.75 & 6.59 & 3.09 & 1.99 \\
\hline $\mathrm{Cr}$ & 6.32 & 21.18 & 14.40 & 34.87 & 8.76 & 40.70 & 18.54 & 27.85 \\
\hline $\mathrm{Ni}$ & 5.21 & 4.17 & 12.00 & 12.61 & 6.57 & 11.63 & 12.36 & 8.62 \\
\hline $\mathrm{Co}$ & 2.45 & 1.98 & 6.96 & 8.16 & 2.41 & 4.26 & 3.61 & 2.65 \\
\hline $\mathrm{Sb}$ & 0.32 & 0.28 & 1.20 & 1.11 & 0.29 & 0.40 & 0.44 & 0.31 \\
\hline $\mathrm{Pb}$ & 1.58 & -0.56 & 8.80 & 8.90 & 3.14 & 2.91 & 13.39 & 6.63 \\
\hline $\mathrm{Cd}$ & 0.08 & 0.06 & 0.06 & -0.06 & 0.06 & -0.08 & 0.41 & 0.13 \\
\hline $\mathrm{Zn}$ & 6.24 & 7.77 & 6.24 & 7.20 & 6.13 & 12.60 & 73.13 & 50.39 \\
\hline $\mathrm{Be}$ & 0.40 & 0.42 & 3.04 & 3.71 & 0.58 & 1.16 & 1.13 & 0.86 \\
\hline $\mathrm{Mn}$ & 8.69 & 12.00 & 13.60 & 14.84 & 13.14 & 25.19 & 37.08 & 25.19 \\
\hline $\mathrm{Th}$ & 1.82 & 2.47 & 3.52 & 5.34 & 1.24 & 1.84 & 1.55 & 1.52 \\
\hline $\mathrm{U}$ & 0.66 & 0.59 & 2.16 & 2.08 & 0.41 & 0.57 & 1.75 & 1.13 \\
\hline
\end{tabular}


Appendix 4. Bibliography of USGS publications resulting from Phase I collaboration.

\section{$\underline{\text { Papers }}$}

Huggins, F. E., Shah, N., Huffman, G. P., Kolker, A., Crowley, S. S., Palmer, C. A., and Finkelman, R. B., Mode of occurrence of chromium in four U.S. Coals: submitted to Fuel Processing Technology.

Kolker, Allan, Palmer, C.A., Crowley, S. S., Finkelman, R. B., Huggins, F. E., Shah, N., and Huffman, G.P., Mode of occurrence of arsenic in four U.S. coals: in preparation for Fuel Processing Technology.

Mroczkowski, S. J., Palmer, C. A., and Finkelman, R. B., in press, Selective leaching characteristics of samples of the Pittsburgh and Illinois \#6 coal beds: Proceedings of the Annual Meeting of the American Chemical Society, Boston, MA, August, 1998, 4 p. (to be published in Fuel Preprints).

Kolker, Allan, and Finkelman, R. B., 1998, Potentially hazardous elements in coal: Modes of occurrence and summary of concentration data for coal components: Coal Preparation, v. 19, p. 133-157.

Kolker, Allan, and Koeppen, R. B., 1998, Arsenic variation in coal pyrite: Proceedings of the Fifteenth Pittsburgh Coal Conference, Pittsburgh, PA, (CD-ROM), September, 1998, 10 p.

Palmer, C. A., Crowley, S. S., Mroczkowski, S. J., Finkelman, R. B., Taylor, K. K., Bullock, J. H., Jr., and Mootoka, J., 1998, The use of sequential leaching to quantify the modes of occurrence of elements in coal: Proceedings of the Fifteenth Pittsburgh Coal Conference, Pittsburgh, PA, (CD-ROM), September, 1998, 28 p.

Senior, C. L., Bool, L. E., III, Morency, J. R., Huffman, G. P., Huggins, F. E., Shah, Naresh, Finkelman, R. B., Crowley, S. S., Kolker, Allan, Sarofim, Adel, Olmez, Ilhan, Zeng, Taofeng, Peterson, Thomas, Farhang, Shadman, Wendt, J. O. L., Seames, W. S., Wu, Baochun, and Helble, J. J., 1998, Toxic emissions from coal combustion: Proceedings of the Fifteenth Pittsburgh Coal Conference, Pittsburgh, PA, (CD-ROM), September, 1998, $12 \mathrm{p}$.

\section{$\underline{\text { Abstracts }}$}

Palmer, Curtis A., Kolker, Allan, Finkelman, Robert B., Mroczkowski, Stanley, J., Willett, Jason C., Kolb, Kathy C., and Bullock, John H., Jr., Arsenic and mercury modes of occurrence in coal: Implications for reducing emissions of these elements from coal-fired power plants: Conference on Air Quality, Mercury, Trace Elements, and Particulate Matter, Mclean, VA, December, 1998. 
Senior, C. L., Bool, L. E., III, Morency, J. R., Huffman, G. P., Huggins, F. E., Shah, Naresh, Finkelman, R. B., Crowley, S. S., Kolker, Allan, Sarofim, Adel, Olmez, Ilhan, Zeng, Taofeng, Peterson, Thomas, Wendt, J. O. L., Seames, W. S., Wu, Baochun, Helble, J. J., and Wornat, M. J., 1997, Toxic substances from coal combustion- a comprehensive assessment: Advanced Coal-Based Power and Environmental Systems Conference, '97, Pittsburgh, PA, July, 1997.

Crowley, S. S., Palmer, C. A., Kolker, Allan, Finkelman, R. B., Kolb, K. C., and Willett, J. C., 1997, Modes of occurrence of HAPs elements in samples from the Pittsburgh, Elkhorn/Hazard, and Illinois No. 6 coal beds: Abstracts and Program, vol. 14, p. 32-33, $14^{\text {th }}$ Annual Meeting of the Society for Organic Petrology/ $26^{\text {th }}$ meeting of the Eastern Section, American Association of Petroleum Geologists, Combined Meeting, Lexington, KY, September, 1997.

Kolker, Allan, Finkelman, R. B., Palmer, C. A., and Belkin, H. E., 1997, Microprobe study of minor- and trace elements in sulfides in selected U. S. coal samples: Geological Society of America, Abstracts with Programs, v. 29, no. 6, p. A-204 to A-205, Geological Society of America Annual Meeting, Salt Lake City, UT, October, 1997.

\section{Published Reports}

Senior, C. L., Bool, L. E., III, Morency, G. P., Huggins, F., Huffman, G. P., Shah, N., Wendt, J. O. L., Shadman, F., Peterson, T., Seames, W., Wu, B., Sarofim, A. F., Olmez, I., Zeng, T., , Crowley, S. S., Kolker, Allan, Palmer, C. A., Finkelman, R. B., Helble, J. J., and Wornat, M. J., 1997, Toxic substances from coal combustion- a comprehensive assessment: Final Report, DOE Contract DE-AC22-95PC95101, U.S. Department of Energy, Federal Energy Technology Center, Pittsburgh, PA, September, 1997. 
Appendix 5 Abstracts of papers prepared for the Phase I special issue of Fuel Processing Technology.

\title{
MODE OF OCCURRENCE OF CHROMIUM IN FOUR U.S. COALS
}

\author{
F.E. Huggins, N. Shah, G. P. Huffman, University of Kentucky, Lexington, KY
}

\begin{abstract}
A. Kolker, S. Crowley, C. A. Palmer, and R. B. Finkelman, USGS, Reston, VA
\end{abstract}
The mode of occurrence of chromium in three U.S. bituminous coals and one U.S. sub-bituminous coal has been examined using both XAFS spectroscopy and a leaching protocol supplemented by SEM/Microprobe measurements. A synthesis of results from both methods indicates that chromium occurs principally in two forms in the bituminous coals: the major occurrence of chromium is associated with the organic macerals and is not readily leached by any reagent, whereas a second, less common occurrence, which is leachable in HF, is associated with the clay mineral, illite. The former occurrence is believed to be a small particle oxyhydroxide phase $(\mathrm{CrOOH})$. One coal also contained a minor amount of a chrome-containing magnetite, and the leaching protocol indicated the possibility of minor $\mathrm{Cr}$ in sulfides in all three coals. There was little agreement between the two techniques on the mode of occurrence of chromium in the subbituminous coal; however, both techniques have limited experience with such coals. All of the chromium was trivalent as no evidence was found for the $\mathrm{Cr}(\mathrm{VI})$ oxidation state in any of the four coals.

\section{MODE OF OCCURRENCE OF ARSENIC IN FOUR U.S. COALS}

Allan Kolker, C.A. Palmer, S. Crowley, and R.B. Finkelman, U.S. Geological Survey, Eastern Energy Resources, 956 National Center, Reston, VA 20192

F. E. Huggins, N. Shah, and G. P. Huffman, Department of Chemical Engineering, University of Kentucky, Lexington, KY 40506-0043

An integrated analytical approach has been used to determine the mode of occurrence of arsenic in samples of four widely used U.S. coals: the Pittsburgh, Illinois \#6, Elkhorn/Hazard, and Wyodak. Results from selective leaching, X-ray absorption fine structure (XAFS) spectroscopy, and electron microprobe analysis show that pyrite is the principal source of arsenic in the three bituminous coals, but the concentration of As in pyrite varies widely. The Wyodak sample contains very little pyrite; its arsenic appears to be primarily associated with organics, as $\mathrm{As}^{3+}$, or to occur as arsenate. Significant (10-40\%) fractions of arsenate, derived from pyrite oxidation, are also present in the three bituminous coal samples. This information is essential to developing predictive models for arsenic behavior during coal combustion and in other environmental settings. 